\title{
Polanyian meditations on economy and society: A review of 'Market Society: The Great Transformation Today'
}

Gareth Dale (draft)

When one considers anthropology's recent encounter with 'globalisation' -- whether understood as a "totalizing" discourse (Tsing 2000), as the dialectical antinomy of localization, as expanding constellations of diasporas and transnational social spaces" (Basch, Glick-Schiller \& Szanton 1994), or as webs of legal and illegal trade (Nordstrom 2007) -- it can be profitable to recall the precursors. By this I mean anthropologists who consistently brought a historical-theoretical concern with global processes to bear upon local ethnography, and vice versa. Those that are name-checked in this connection tend to include Marxian theorists such as Eric Wolf, Michael Taussig, Sidney Mintz, and Maurice Godelier, but another important figure was Karl Polanyi.

Polanyi was the muse behind a recent workshop held at the Max Planck Institute for Social Anthropology, from which the volume 'Market Society: The Great Transformation Today' emerged. Its contributors -- a dozen anthropologists, a couple of economic sociologists and an economist - were given two tasks: to brainstorm on economic anthropology today, with Karl Polanyi's work as their pole star, and to reconsider his theories in the light of present-day circumstances. That they adhered to this guidance gives this ensemble of essays a genuine intellectual coherence. The unifying threads comprise a set of methodological and political tenets: a consensus on realism and against social constructivism; a constructive re-evaluation of Polanyi's ideas; a preference for fieldwork-based ethnography that engages with theoretical debate and with new perspectives on the global economy and world history; and a dedication to the development of what the editors term "a more humane approach to economy" and "a critical commentary on capitalist civilization" (pp.10, 13).

\section{The intractable ambiguities of 'embeddedness'}

Although no anthropologist, Polanyi avidly studied Malinowski, Firth and Mead, as well as Richard Thurnwald -- to whom he would write "my indebtedness to your work was great from the start" (Polanyi 49-2). ${ }^{1}$ The main narrative of Polanyi's The Great Transformation consists of a detailed explanation as to why the market economy hit the buffers in Western Europe and North America in the nineteenth and twentieth centuries, but its theses on the novelty of the market economy and the behavioural type that it spawns (homo economicus) drew support from ethnographic materials on small-scale societies in which price-making markets are absent, individual gain-seeking is generally spurned and mutual aid-oriented behaviour is favoured. More than the anthropologists just mentioned, Polanyi was interested in generalizing from the new ethnographic data, putting it to use to debunk the myth of economic man and in the process to open up new vistas in the comparative study of systems of exchange. What thrilled him about the emerging evidence was that the lack of a primary orientation to material gain displayed by 'primitive' people was evidently a function of the structure of their society, and this opened a window onto new ways of construing 'the economy' that were radically

References of the form " $1-10$ " are to box and folder numbers of materials in the archive of the Karl Polanyi Institute for Political Economy, Concordia University. 
different to the contemporary capitalist norm. In the Pacific islands investigated by Firth and Malinowski 'purely economic' institutions did not exist; nor did 'the economy' assume the form of a separate and distinct sphere. Rather, economic structures (division of labour, patterns of distribution, etc.) were overdetermined by non-economic values and institutions: 'community' absorbed 'economy'; it directed it, or infused it with its values, rather than being governed by it as in liberal capitalism. In this sense the economic systems of 'primitive' societies were invisible: they were submerged in the totality of social relationships.

Polanyi's preferred metaphor when referring to the relationship between economy and society, 'embeddedness,' is a term with which a host of etymological and conceptual tangles are associated, and some of these are addressed in this volume - most extensively by the economic sociologist Jens Beckert. Although Polanyi is usually referred to as the originator of the concept of embeddedness, writes Beckert (p.40), citing Raymond Firth (1972: 473), it was in fact "used earlier by Richard Thurnwald in his Die menschliche Gesellschaft." Yet, Thurnwald's usage refers to the fact that individual economic activity is rarely isolated but is instead, as a rule, plugged into the broader economic activity of the community. Used thus, embeddedness is roughly synonymous with 'economic cooperation' or 'division of labour.' Thurnwald possessed a strong conception of the "sozialpsychische Verflochtenheit" of economic life -- a kindred concept to Polanyi's embeddedness - but he did not, to my knowledge, refer to that relationship with the metaphor eingebettet (Thurnwald 1932: 44-45).

If we assume that Polanyi borrowed the term from Thurnwald, he subjects it to two alterations. First, the 'ground' in which individual behaviour is embedded is not the cooperative economy but society as a whole. Thus, in his notes on Coming of Age in Samoa in the mid-1930s, he pens the term 'embeddedness' against this paraphrase of Mead: "The emphasis was never upon what an individual did, neither upon his skill nor upon the size of his catch or harvest, but always upon its place in a larger social situation" (Polanyi 7-9; emphasis added). Second, and crucially, the term's referent broadens out from individual behaviours to the relationship between sets of social relationships (economy, society).

Whether or not he coined the term, Polanyi made the concept of embeddedness his own. But his usage is not without its own problems. It is possible, explains Beckert (p.41) "to identify two core meanings the concept had for Polanyi." The first, a diagnostic approach, holds that the economic institutions of functioning societies must be regulated, and connected to the moral fabric of society and that, conversely, unregulated markets cannot be more than a pathological form of economic organization, generative of social anomie. In the second approach 'embeddedness' is not only an analytical term,

but also alludes to the political or social reformist task of stabilizing a (democratic) organization of society through the institutional regulation of markets, especially in the realms that Polanyi termed fictitious commodities: land, labor, and money.

What has occurred in recent decades, and here we arrive at the nub of Beckert's argument, is that while embeddedness has gained a hallowed status in economic sociology -- to the point that (p.40), "few economic sociologists would disagree with the statement 'We are all Polanyians now'" - in the same movement "the social-reformist connotations of the concept" have been all but forgotten. The figure who can claim greatest responsibility both for the popularization of the concept and for the eclipse of its reformist connotations is the economic sociologist, Mark Granovetter. His 1985 article brought embeddedness its current prominence but at the cost of some considerable confusion. 
Granovetter's aim was to chart a course between two "extreme" positions: a utilitarian 'undersocialized' conception of man that plays down the influence upon economic behaviour of non-economic norms and institutions, and an 'oversocialized' conception, represented by the argument of Polanyi and others "that the behaviour and institutions to be analyzed are so constrained by ongoing social relations that to construe them as independent is a grievous misunderstanding" (Granovetter 1985: 481-482). In what one may charitably assume to have been a slip of the pen, at different stages in the argument Granovetter identifies both the Polanyian "extreme" and his own middle course as "the embeddedness approach" (Granovetter 1985: 481-482, 487; emphasis added). It may be regarded as a "comedy of errors," in Beckert's phrase (p.43), one that has been recently compounded by Granovetter's revelation that, when perusing his old notebooks, he found that his use of the term predates his discovery of Polanyi.

For Granovetter, economic behaviour in market societies is rooted in socialized networks. His approach is sometimes known as the 'network approach,' because embeddedness is taken to denote "the way social and economic activities are mixed up with networks of social relations" (Granovetter 2004). In accounting for the behaviour of market actors priority is given to structures of social networks and the positions that individuals hold within them rather than ethical commitments or institutional arrangements. It is an approach that isolates "a single aspect of markets - networks of ongoing social relations -as constituting the proper domain of economic sociology" (Beckert p.42), as contrasted with Polanyi's institutional approach, for which "markets are not networks of structurally equivalent producers but rather fully social institutions, reflecting a complex alchemy of politics, culture, and ideology." Polanyi's "thick" version of embeddedness, as Don Robotham puts the matter in the concluding chapter of the volume (p.273),

does not see the institutional framework as facilitating or arising from self-seeking calculation, but rather represents it as its very antithesis. It is made up of non-rationalist elements expressing values that are ends in themselves. It is Gemeinschaft - community - struggling to constrain the alienating forces of 'contingency'.

Embeddedness, in short, has become recognized as a pivotal Polanyian concept but only as the result of "cumulative interpretative misunderstandings on several levels" (Beckert, p.43), not the least of which is its confusion with a quite alien concept, Granovetter's.

For Beckert (p.51), the conclusion for sociologists who claim inspiration from Polanyi is clear. Their investigations should not be restricted to surveying "the social and political preconditions for the efficient fulfilment of economic functions." The appropriate questions, rather, should concern the effects of the organization of the economic system upon society as a whole: how does economic globalization affect social solidarity?, what impact does the increasing insecurity of employees caused by new employment regimes have on family structures?, how does the expansion of markets affect social inequality, working conditions, and local communities?, and, finally, how are actors responding to the increasing uncertainties they face in consequence of the marketization of 'fictitious commodities'?

\section{From 'Great Ditch' to Great Wall}

The notion that 'the economy' is entangled with other spheres of life, notably religious practices, is by no means unique to Polanyi. Leaving the ancients to one side, it was taken 
for granted by Adam Smith, whose Moral Sentiments, Robotham points out (p.280), "argued that the extension of market relations brings with it not only utilitarian attitudes and self-seeking relationships, but also the broader sympathies of society, civic culture, and humanity they help to create." It was a core concern for the German Historical School, for nineteenth-century anthropologists, and it formed the explicit theoretical thrust of Der Güterverkehr in der Urgesellschaft, by the economic anthropologist Bódog Somló (1909), Polanyi's doctoral supervisor -- which electrified him when he stumbled across it in 1948. The idea was enriched by contemporaries of Polanyi, including of course Malinowski and Thurnwald but also a personal friend, Richard Tawney, in his Religion and the Rise of Capitalism. Yet Polanyi's stance was distinctive. Of all the thinkers mentioned, none charts quite such a sharp disjuncture between the 'disembedded' nature of contemporary market society and all that went before. His interpretation of world history was "deceptively simple," as Chris Hann and Keith Hart observe in their Introduction (p.5), in that "he presented the emergence of 'market society' in the nineteenth century as a radical break" -a 'Great Ditch,' not unlike the one that Ernest Gellner posits between Industria and all preceding social formations (Agraria).

Yet Polanyi's Great Ditch is girdled by some thorny puzzles. There is, Keith Hart notes (p.103) a "lingering confusion" over whether he believed a 'disembedded' market economy to be an observable phenomenon "or just a figment of liberal ideology" - and if merely the latter, his 'Ditch' is shallower than would otherwise be assumed. More generally, argue Hart and Hann, he lacks clarity on the "embedded" character of modern capitalism, neglecting to identify "important features of the bureaucratic capitalism that built up in the late nineteenth century" (p.6). This was a period of "national capitalism" in which state and market formed a synthesis characterized by "the institutional attempt to manage money, markets, and accumulation through central bureaucracy" as well as the rise of large corporations. In consequence The Great Transformation failed to anticipate the postwar entrenchment of "national capitalism" (Hart p.103); his vision "was effectively refuted from the 1940s onward," (Hann and Hart p.8), by Keynesianism (with which Polanyi "never engaged in detail"), and by many capitalist governments that espoused social-democratic principles, from post-New Deal USA to Nehru's India. In this critique, something approaching a consensus emerges, with Phillipe Steiner charging Polanyi with a neglect of the actual functioning of the present market system (pp.59-60) and Robotham suggesting that "his focus on markets diverts attention from the growth of large transnational corporations whose monopolistic behavior is the very antithesis of liberalism," a matter about which "Polanyi had nothing to say" (pp.283). The criticism, it seems to me, is persuasive - except for Robotham's. As that high priest of liberal economics, Ludwig von Mises, once argued, monopolies and giant corporations are entirely consistent with liberalism and the free-market system, so long as they remain Sondereigentum (Mises 1932: 354-362). In fact, Polanyi did extensively discuss the rise of giant corporations, but erroneously believed these to signify a continuation of the 'great transformation' away from market society.

An alternative detour around the Great Ditch is proposed in his chapter by Stephen Gudeman. In a creative redrafting of the 'embeddedness' concept, he proposes that although Polanyi's metaphor is richly suggestive, it is hampered by its deployment on behalf of a historicist model, such that a disembedding logic is introduced into history by the advent of the market economy in nineteenth century Britain. Against this approach he proposes a universal dialectic of mutuality and market, of Gemeinschaft and Gesellschaft. All economies, he maintains (p.18) "are both embedded and disembedded." In every economy 
two value realms exist side by side. Designated mutuality and market, or community and impersonal trade, the operative difference between the two may be characterized "as the distinction between a commitment and a contract, or the difference between an activity undertaken 'for its own sake' and one done 'for the sake of" something else.'" No pure economy of mutuality has existed, nor its antithesis, an economy of impersonal exchange; the two dimensions are necessary and symbiotic. Gudeman makes his case well, but, as Robotham remarks (p.275), this model makes it difficult to conceive of a 'Great Transformation': "If trust and exchange are variously mixed in any concrete case, how does Polanyi's entire historical perspective hold up?"

An equally far-reaching modification of Polanyi's model, albeit one that retains the notion of 'great transformation,' is advanced by the Halle-based anthropologist Chris Hann. At the theoretical level, his emendation of Polanyi maintains that a socially disruptive Great Transformation may result from a 'sudden exaggerated emphasis' not only of market exchange but also of Polanyi's other 'mechanisms of integration' too redistribution or reciprocity (p.207). His case study is China, a country on which Polanyi himself did not write, apart from the occasional passing comment in the 1930s - for example that in international diplomacy "We should model ourselves on China which is and was based on the tolerance of other peoples' ways of life" (Polanyi 20-4). On Mao's China he said little, although did argue that it represented "a step ahead of capitalism" (Polanyi 54-5).

With Polanyi's Communist sympathies in mind, Hann notes the irony of his own position, which compares China under Mao to nineteenth-century Britain: "a general moral disembedding induced by political coercion rather than the market," which was no less devastating for the balance of social relations than were the market-driven processes analyzed by Polanyi (pp.258-263). The irony is compounded by the second step in his argument, which suggests that market reforms in China are analogous to Polanyi's 'protective counter-movement.' The reintroduction of the market, recent Chinese history shows, "can be consistent with a renewal of moral embeddedness, analogous to the embedded liberalism of the Keynesian generation in the West" (p.258).

Hann's thesis applies at the national level, but draws heavily upon fieldwork in a rural part of the province of Xinjiang, at the westernmost extremity of the Great Wall. Its remoteness from the commercialized eastern seaboard notwithstanding, the region's incorporation into the global economy has been accompanied by rapid socioeconomic transformation, characterized by the expansion of the market principle, the intrusion of 'general-purpose' money into new spheres and the rapid growth of private market activity (particularly in cotton production, for which the government no longer insulates producers from volatile price fluctuations). That said, the Xinjiang authorities are committed to maintaining "a balance of economic principles" in rural areas and have charted some success in this: reciprocal and redistributive mechanisms do indeed function effectively as checks and balances to market forces; neither labour nor money have been "been reduced to the status of fictitious commodities as defined in Polanyi's 'ideal type' or as found in practice in contemporary capitalist economies" -- and this is even more true of land, which in many areas "is seldom farmed by anyone other than the designated holder of the use rights." Of course, market exchange is on the rise, "but it is modified by redistribution undertaken both by the state and by kin and neighbors in accordance with Islamic precepts." Some villages exist economically as "highly autarkic units in which most work is unpaid and subject to the patriarchal structures of the household," while rural life in general benefits from robust networks of hospitality and reciprocal gift-giving 
(including the provision of labour by kin at harvest time). In sum, China today - which at the national level corresponds to "the mix of economic principles observable in some eastern Tian Shan villages" -- can be seen "as a balancing act, as a socialist equivalent of the welfare state, the "embedded liberalism" which prevailed in the West in the decades following the Second World War" (p.270). Embedded socialism has arrived in China, but half a century after Polanyi thought it had.

Hann's case is original and innovative; it also raises the important question of what is it about state power that enables it to create social 'disembedding' analogous to that effected by market expansion. But is the thesis that China has been experiencing an 'embedding' process persuasive? As Robotham points out (p.282), the extension of market relations has coincided with a dramatic rise in social inequality. The suggestion that China's welfare system is robust is also open to doubt: peasants and workers are obliged to save in order to provide the security against ill health, unemployment and old age that the state no longer provides -- if the rice bowl was ever ferrous those days are long gone. As is well known, this has been a major factor behind the country's astonishingly high savings ratio, and this, in turn, played a part in supporting that unsustainable explosion of debt in the USA and elsewhere which accounts for the depth of the current global recession.

This last point reminds us of the interactions between nation states and social/economic forces at the international level, a relationship to which Hann pays scant attention. In his discussion of redistributive economies this neglect characterized Polanyi's work too. The dirigisme of almost all the societies he admired, including Sumer, Classical Athens, Ptolemaic Egypt, Dahomey and the Soviet Union, arose in connection to the exigencies of coping with the pressures of a threatening security environment, but this only appears at best in the margins of his discussion. Mao's China, too, was war-economic in nature. Given its backwardness relative to the superpowers against which its forces were ranged (and sometimes clashed), the need to set military priorities was felt with uncommon force; the arms race set very powerful imperatives that overdetermined all subsidiary decisions down to how much investment could be devoted to agriculture. Neither the 'redistributive' character of the Maoist period nor the success of the market reforms under Deng can be properly understood without reference to the geopolitical and geo-economic context.

\section{The blessings of money, the violence of debt}

In terms of the dual challenge this volume sets itself - to showcase fieldwork-based ethnography that pursues Polanyian questions as well as more theoretically inclined essays that utilize Polanyian concepts to generate a critical analysis of the world economy as a whole - the chapter by one editor, Chris Hann, represents the first while that of his colleague, Keith Hart, exemplifies the second. His topic of choice, as in his earlier works, is money: its dialectical and liberatory qualities, not the least of which is its enabling role in the development of a truly global society. "Instead of being denigrated for its exploitive power," he proclaims (p.92), money "should be recognized for its redemptive qualities, in particular as a mediator between persons and society." Along with language, money is one of the great means of communications, but unlike language ("which divides us more than it brings us together" (p.101)) it evinces the "potential for universal connection" -indeed, it is "the most tangible manifestation of the new human universal that is our 
shared occupation of the planet," and "must be central to any attempt to humanize society" (p.100).

One might suppose that this is the antithesis of Polanyi's approach. Widely regarded as a Romantic he has been chided, by the anthropologist Maurice Bloch among others, for the "oversimple contrast" he presents "between a pre-monetary state of affairs and a postmonetary state of affairs where the former is nothing more than an antithesis to a nightmarish view of commerce" (Bloch 1989: 170). Charges of this sort are legion, but they are crass misrepresentations that don't withstand scrutiny. Far from being distrustful of money, Polanyi champions it, remarking that it

induces in men's consciousness an identification between a number of otherwise widely different human situations as long as these bear reference to the same quantities. This extends the scope of our intellectual and moral experience and creates social relationships of a kind that may well be said to transform the whole of life.

Polanyi 33-4; emphasis added

Like Hart, Polanyi was fascinated by money's resemblances with language and writing, in that money-objects, just like sounds and letters, are "organized in an elaborate code of rules concerning the correct way of employing the symbols" (Polanyi 1968: 178). Yet, unlike Hart, the comparison with language is not made with an eye to the universal communication that each enables in their different ways, but to distinguish its modern form from archaic and 'primitive' incarnations: it is only "modern money" that resembles "both language and writing" (Polanyi 1968: 178). Circulating throughout the economy it fulfils a number of functions -- means of exchange and of payment, and store of and standard of value -- and in order to do so must possess a qualitative uniformity. The various money uses in archaic and 'primitive' societies, by contrast, may be utterly heterogeneous, and be supplied by different money objects. Such societies

did not know 'all-purpose' money. Various money-uses may be supplied here by different money objects. Consequently, there is no grammar with which all money-uses must comply. No one kind of object deserves the distinctive name of money; rather the term applies to a small group of objects, each of which may serve as money in a different way. While in modern society the money employed as a means of exchange is vested with the capacity of performing all the other functions as well, in early society the position is rather the reverse. One encounters slaves or horses or cattle used as a standard when judging of prestige-conveying wealth, or anyway of large amounts, while cowrie shells are solely employed for small amounts.

Polanyi 1968: 178

For this reviewer Hart presses his point on the 'connecting' function of money a bridge too far, and to the neglect of power relations - much as Habermas on language. At one point he does concede (p.92) that money "currently serves" the engines of social inequality, yet a few pages later he credits it (p.100) with providing individuals with a repertoire of instruments with which "to calculate the current balance of their worth in the community" a notion from which those without much of it, or who assess their 'worth' by alternative means, may be expected to demur. Some may also take exception to Hart's asseverations that "money must be central to any attempt to humanize society" (p.100), and that it, together with markets, are "human universals" (p.92). And yet, even if Hart does not always completely convince (and he usually does), his chapter is a pleasure to read, and sparkles with fresh ways of seeing. 
Equally riveting is the succeeding chapter by the London University anthropologist David Graeber (based upon an earlier piece published in Mute: Culture and Politics After the Net). Whereas Hart invests hope in the webs spun by economic globalization in general and money in particular, Graeber's lens is darker; his focus is upon the imbrication of money and credit with relationships of political power and exploitation. The sharpest critical thrusts are in this chapter - as in the insight that ideologies of debt "have been and continue to be the single most effective way of making human relationships created and maintained by violence seem to be rooted in morality" (p.125). Yet general statements of this sort are interspersed with sedulous analysis, in particular on the origin and history of money.

On money, Graeber draws heavily upon Michael Hudson's work, which may be described as a pluralist and open variant of chartalism. Hudson locates money's origins in three separate tributaries, each of which represents payment of a distinct form of debt (Hudson 2004a: 99; see also Hudson 2004b). One is wergild-type debts to compensate victims of manslaughter or injury; a second is food and other contributions to commonmeal guilds and brotherhoods; and the third evolved in the temples and palaces of third millennium Sumer as a unit of account by which commensurability, and thence prices (in silver weight-equivalency), were established in order to assist the various departments of the temples and palaces in administering their transactions with one another and with other actors, with regard to the value of crops, rents, fees and commodity purchases.

This was also Polanyi's approach, in its theorization of money's origins in multiple processes, its identification of the seminal role of Sumerian staple finance, and its insistence that debts and obligations antedated the existence of markets (Polanyi 35-11). But whereas Polanyi marvelled at Mesopotamian society for bringing forth the world's first states, money and interest-bearing loans, for Graeber this chalice was poisoned. While acknowledging that Mesopotamia's rulers often acted in the interests of social cohesion by periodically eliminating debts, he appears to regard states and usury as the twin evils of human civilization, and this prompts him to pursue a question that would scarcely trouble a mainstream chartalist:

How do social obligations, rights, and duties that people have with one another end up becoming attached to objects of material wealth, so that the mere transfer of such objects can often render one person entirely at another's command?

Beyond this, even larger issues make an appearance, not least the question "how does one relate a theory of value to a theory of debt?" (pp.111-12).

Graeber makes a forceful case that there is work to be done in these areas. By and large, he points out, anthropologists have had little to say about the phenomenon of debt - and this should surprise, given that they have had much to say about social obligation. Fast forward to the present day and a similar neglect can be observed. The current era might be said to have been initiated on August 15, 1971, when President Nixon closed the 'gold window,' in effect founding the current floating currency regime. We have returned, then, to an age of virtual credit-money but one which, in a reversal of the narrative of The Great Transformation, ushered in a financialized neoliberal order - an order, moreover, in which the hegemonic power has learned to use its mountainous debt as a means of leverage over creditors. ${ }^{2}$ The modern state, Graeber continues,

is often said to have emerged through deficit financing; the economies of wealthy countries are now

As the late and greatly missed Peter Gowan explained in The Global Gamble: Washington's Faustian Bid for World Dominance (1999). See also Michael Hudson (2002). 
driven largely by consumer debt; international relations are increasingly dominated by the debt bondage of the poor to the International Monetary Fund (IMF) and the World Bank and by the debt of the United States to East Asia. Yet there is remarkably little written about the nature of debt itself.

Throwing up questions of this scope, one could hardly expect Graeber to provide detailed answers, and indeed he does not. Rather, his chapter is a 'promissory note' - upon which, one hopes, he will not default.

\section{Market society, neoliberalism and the 'third sector'}

The coherence of 'Market Society: The Great Transformation Today', I mentioned at the outset, derives from a set of shared assumptions: that anthropological fieldwork can usefully draw upon Polanyian theory to address economic issues from a critical perspective. Within that broad remit, there is leeway for extensive zones of disagreement, and sharp differences in emphasis. Graeber's criticisms of the existing order (p.106) are the most thunderous in tone: "the free-market ideology that Polanyi felt was gone forever in the 1940s has returned with a vengeance - returned to reap a terrible vengeance, in fact, on the most vulnerable people of the earth." Several other chapters delineate and critically evaluate contemporary neoliberal strategies. In one, a study of marine conservation in Jamaica, James Carrier subjects to critique the commodification of labour and the commercialization of coastal waters. In another, Catherine Alexander presents the findings of her research into community recycling projects in southern England. Such schemes are sometimes held up as harbingers of a 'third sector' alternative to bureaucratic states and markets, but Alexander expeditiously debunks this fantasy, drawing attention to the "divergence between public rhetoric of freeing society from statist intervention and the practice of entangling third-sector groups into contractual relations with the state" (p.221). The autonomy of the third sector, she continues, "is being eroded as it becomes little more than an instrument of the state, providing 'public' services of welfare and environmental concern while internalizing the risks of operation." Meanwhile, the state increasingly acts as to inject market methods into its own and 'third sector' operations, and lends its weight to the idea of the 'consumer citizen' - "that proper citizen activity involves market behaviour." Few third sector enterprises are in a position to resist such impositions - for, according to one survey, only three percent of them are self-reliant with sixty-seven per cent wholly dependent upon government funding (p.234).

Along such routes the march of market society can appear to be continuing, unimpeded. Even as I write, it has been announced that higher education in Britain, which once merited a government department of its own, has been incorporated into Lord Mandelson's Department of Business, while in the subsequent news item we hear that the government is determined to return recently nationalized banks post-haste to private hands. But what of the longer run, and the wider world economy? In Keith Hart's judgment (p.102) "We are clearly witnessing the start of another long swing in the balance between state and market." Initially, this has taken a regressive form, with states snaring resources from taxpayers, present and future, with which to shore up the big banks, but "before long, a genuine revival of Keynesian redistributive politics seems to be inevitable." I am not so certain of this; and would note that although a Keynesian dawn has made an appearance over China, it may not be a 'real' one. However, alongside his hopeful forecast Hart also raises the possibility of "another round of disasters such as those Polanyi attributed to reliance on 'free' markets for social organization" (p.8) and, in 
characteristically arch mode, predicts "an escalation of war and general fractiousness" (p.104). These are forceful predictions, yet at one pivotal point a hesitancy appears. After arguing passionately that capitalism continues to be instrumental in the formation of a "world society" (p.94), he concedes that its late twentieth-century phase of globalization has severely exposed the limitations of national frameworks of economic management, such that (p.102) it is "no longer obvious, as it was for Polanyi and Keynes, where the levers of democratic power are to be located."

If Hart makes a cautious wager on economic globalization, Robotham is positively gung-ho: "Without a further extension of market relations, a solution to the alienation and exploitation created by capitalist modernity is hard to conceive" (p.280). Capitalism's liberatory journey is not over: it continues to "emancipate us from parochialisms and relations of personal dependence" -- and for failing to see this, Polanyi stands accused. His "relatively uncritical attitude to past economic formations and a failure to see any merit in the expansion of capitalist relations (including the labor market) justifies pinning the label 'nostalgic' on Polanyi's thought and on many of those who follow him," including several contributors to this volume.

Although widely held, this criticism of Polanyi is largely unwarranted. The more persuasive part of Robotham's criticism is that Polanyi's attitude to past societies was uncritical, but even here the issue is complex. He did downplay the oppressive and exploitative features of 'redistributive' societies such as Ancient Mesopotamia and Classical Athens but this was less a result of nostalgia than of an uncritical attitude to all statist societies formations, including the Soviet Union, and it related in addition to what Geoffrey de Ste Croix once called his tendency to neglect "nasty things like exploitation and class struggle" (de Ste Croix 1969). The other parts of Robotham's critique are still less convincing. Polanyi - along with other socialists - did indeed credit capitalism with a progressive historical role, but believed this to have become superseded as alternatives emerged. His formulations on this subject tend to be dialectical, and nuanced. For example, "While the action of the market called forth widespread reactions and helped to create a strong popular demand for political influence of the masses, the use of the power so gained was greatly restricted by the nature of the market mechanism" (Polanyi 19-17). He did believe that capitalism had had its day, was outdated, harmful to human beings and the environment, and should be replaced, but that is not to say that it had brought forth nothing of value.

The question of Polanyi's 'nostalgia,' similarly, should be viewed dialectically, and with attention to historical context. Even in his youth, his 'nostalgia,' such as it was, was alloyed to a thoroughly modernist outlook. He belonged to a generation of restless radicals of whom Mary Gluck has observed "Their inability to find genuine roots in the stony soil of turn-of-the-century Hungary" produced "not detachment but a strong nostalgia for the possibility of a community that kept eluding them" (1985: 73). Polanyi reacted against the materialistic, utilitarian civilization of the late nineteenth century with passionate hatred, convinced that the material gains of progress had been made at the price of a devastating spiritual loss; he shared with conservatives a melancholic awareness of "life as it was, and is not, and should be." However, unlike them, he made no attempt to recapture the traditions of bygone ages. He searched in the past for ideal instances of nonalienated cultures but, rather than pining for the 'dead old' he was a modernist through and through, aspiring to a society that would be capable of welding the Gemeinschaft of the old to the universalism, egalitarianism and democracy of the new. 
It is the conjoining of a perspective on past societies that is free from condescension with a lifelong idealist commitment to progressive social change that made Polanyi's theory what it was. In his comparative approach to pre-modern societies he carefully delineates their differentia specifica and in the process serves to denaturalize, defamiliarize and in so doing further our understanding of the modern market economy. The intellectual tradition from which he came, moreover, was preoccupied with the meaning of human history and the future of liberal civilization, and his own research was geared to questions on that grand scale. His aim was to comprehend the character and trajectory of an entire epoch, combining a holistic philosophy with wide-ranging comparative analysis and an eye for empirical detail. He tackled the big issues, setting an example for social scientists today when, although research and publications tend to be focused on narrower issues than in his time, the challenges humanity facing are greater still. At its best, this volume is a worthy inheritor of Polanyi in its engagement with what one contributor terms "grand sweeping theory" and its commitment to the "imagining of alternatives" (pp.106-7). 


\section{Works Cited}

Polanyi references of the form "1-10" are to box and folder numbers of materials in the archive of the Karl Polanyi Institute for Political Economy, Concordia University.

Basch, Linda, Nina Glick-Schiller and Cristina Szanton. 1994. Nations Unbound:

Transnational Projects, Postcolonial Predicaments and Deterritorialized Nation-States.

New York: Gordon and Breach Publishing.

Bloch, Maurice. 1989. 'The symbolism of money in Imerina'. In M. Bloch and J. Parry, (eds.), Money and the Morality of Exchange. Cambridge: Cambridge University Press.

de Ste Croix, Geoffrey. 1969. Letter to Moses Finley 12.11.1969 [Correspondence passed to author by Daniel Tompkins].

Firth, Raymond. 1972. Methodological issues in Economic Anthropology. Man 7(3): 467-475.

Gluck, Mary 1985. Georg Lukács and his Generation, 1900-1918. Cambridge: Harvard University Press.

Gowan, Peter. 1999. The Global Gamble: Washington's Faustian Bid for World Dominance. New York: Verso.

Granovetter, Mark. 1985. Economic Action and Social Structure: The Problem of Embeddedness. American Journal of Sociology 91(3): 481-510.

Granovetter, Mark. 2004. Opening Remarks on Embeddedness. In G. Krippner et al., 'Polanyi Symposium: A Conversation on Embeddedness' Socio-Economic Review 2(1):109-135.

Hudson, Michael. 2002. Superimperialism: The Origins and Fundamentals of U.S. World Dominance. London: Pluto Press.

Hudson, Michael. 2004a. 'The Archaeology of Money in Light of Mesopotamian Records'. In L. R. Wray, (ed.). Credit and State Theories of Money: The Contributions of A. Mitchell Innes. Cheltenham: Edward Elgar Publishing: 99-127.

Hudson, Michael. 2004b. 'The Development of Money-of-Account in Sumer's Temples'. In M. Hudson and C. Wunsch (eds.). Creating Economic Order: Record-keeping, Money and the Development of Accounting in the Ancient Near East. Baltimore: CDL Press: 303-329.

Mises, Ludwig. 1932. Die Gemeinwirtschaft: Untersuchungen über den Sozialismus. Jena: Gustav Fischer.

Nordstrom, Carolyn. 2007. Global Outlaws: Crime, Money, and Power in the Contemporary World. Berkeley: University of California Press.

Polanyi, Karl. 7-9, 'Origins of Institutions'. Emphasis added.

Polanyi, Karl. 19-17. 'The Eclipse of Panic and the Outlook for Socialism.'

Polanyi, Karl. 20-4. 'Common Man's Masterplan' [1939-40].

Polanyi, Karl. 33-4. Emphasis added.

Polanyi, Karl. 35-11. Draft manuscript of Livelihood of Man.

Polanyi, Karl. 49-2. Letter to Richard Thurnwald. 04.12.1953.

Polanyi, Karl. 54-5. From an incomplete letter. n.d.

Polanyi, Karl. 1968. Primitive, Archaic, and Modern Economies. G. Dalton (ed.). New York: Anchor Books

Somló, Bódog [Felix]. 1909. Der Güterverkehr in der Urgesellschaft. Brussels: Misch \& Thron. 
Thurnwald, Richard (1932) Die menschliche Gesellschaft, Band 3: Werden, Wandel und Gestaltung der Wirtschaft. Berlin: Walter de Gruyter.

Tsing, Anna. 2000. The Global Situation. Cultural Anthropology 15(3): 327-360. 